\title{
Ustilaginoidea virens Infection of Rice in Arkansas: Toxicity of False Smut Galls, Their Extracts and the Ustiloxin Fraction
}

\author{
Hamed K. Abbas ${ }^{1 *}$, Wayne Thomas Shier ${ }^{2}$, Rick D. Cartwright ${ }^{3}$, Gabe L. Sciumbato ${ }^{4}$ \\ ${ }^{1}$ United States Department of Agriculture, Agriculture Research Service, Biological Control of Pests Research \\ Unit, Stoneville, USA \\ ${ }^{2}$ Department of Medicinal Chemistry, College of Pharmacy, University of Minnesota, Minneapolis, USA \\ ${ }^{3}$ University of Arkansas Division of Agriculture, Cooperative Extension Service, Little Rock, USA \\ ${ }^{4}$ Delta Research and Extension Center, Mississippi Agricultural and Forestry Experiment Station (MAFES), \\ Stoneville, USA \\ Email: ${ }^{*}$ Hamed.Abbas@ars.usda.gov
}

Received 14 August 2014; revised 17 September 2014; accepted 10 October 2014

Copyright (C) 2014 by authors and Scientific Research Publishing Inc.

This work is licensed under the Creative Commons Attribution International License (CC BY).

http://creativecommons.org/licenses/by/4.0/

(c) (i) Open Access

\begin{abstract}
Cool, wet conditions in the southern US during the maturing stages of rice in 1998 contributed to outbreaks of false smut caused by Ustilaginoidea virens. Water extracts of false smut galls in Asia have been reported to contain ustiloxin toxins, cyclic peptide antibiotics that interfered with microtubule function and caused "lupinosis"-like lesions in mice. Cell-free extracts from false smut galls on rice grown in Arkansas were fractionated by a published procedure for the purification of ustiloxins. The ustiloxin fraction was phytotoxic to Lemnapausicostata (duckweed) at $\geq 19 \mu \mathrm{g} / \mathrm{ml}$, but the host plant, rice, was much less susceptible, exhibiting phytotoxic effects in germinating seeds at $\geq 1000 \mu \mathrm{g} / \mathrm{ml}$. The aqueous extract of rice false smut galls showed no cytotoxicity to mammalian cell cultures at $200 \mu \mathrm{g} / \mathrm{ml}$, but the ustiloxin fractionwas cytotoxic at $10-100 \mu \mathrm{g} / \mathrm{ml}$. However, rice false smut galls were not toxic when fed to mice at $\mathbf{1 0 \%}$ of chow, but caused feed refusal at higher concentrations. We conclude that for 1 ) the $U$. virens which causes false smut in southern USA differs from Asian isolates in that does not produce detectable ustiloxins; and 2) false smut affects the appearance, but not the food safety of rice in the United States.
\end{abstract}

\section{Keywords}

Phytotoxicity, Cytotoxicity, Mouse Toxicity, Ustiloxins, Chlamydospores

\footnotetext{
${ }^{*}$ Corresponding author.
} 


\section{Introduction}

Rice (Oryza sativa L.), wheat (Triticumaestivum L.) and maize (corn, Zea mays L.) are the three most important food crops in the world [1]. Rice is the most important foodstuff in Asia, where it is the staple food of 1.3 billion people, supplying up to half the calories consumed. It is the second most widely consumed foodstuff worldwide supplying $21 \%$ of global human energy. Millions of small farmers in Southeast Asia depend on the rice crop for cash income and to feed their families [1]. In the US, rice is produced mostly in Arkansas, California, Louisiana, Texas, Missouri and Mississippi and accounts for more than 34 billion dollars of economic impact, with approximately half being exported to other countries [2]. Consumption of rice is lower in the US than in Asia, representing only about $3 \%$ of US calories, and much of it in processed foods.

False smut, caused by Ustilaginoidea virens (Cooke) (Takahashi) [teleomorph: Villosiclavavirens] [3]-[10], is one of numerous fungal, bacterial, and viral diseases which cause crop losses in rice [3]-[5]. U. virens produces conidia, secondary conidia, chlamydospores, sclerotia and ascospores, all of which are capable of infection. $U$. virens overwinters by producing fungal structures called sclerotia, which contain chlamydospores (resting spores) and compact masses of mycelia [11]-[14]. These structures enable the fungus to survive for at least 4 months under field conditions. $U$. virens infects rice kernels causing greenish to black balls on individual kernels, which swell to at least twice the size of mature rice kernels. During its life cycle, $U$. virens produces a reproductive stage, which consists of the sexual ascospores, and an asexual stage known as a chlamydospore. Both stages play a very important role in the initial steps of the $U$. virens infection process [14]. The sexual stages of $U$. virens are known as Villosiclava virens because of similarities to the Claviceps genus in teleomorphic properties [15]-[17]. False smut galls have been reported to emerge about 20 days after the initial infection of kernels of the rice panicle during flowering of the rice plant; however the time frame in the US is not well understood. The false smut pathogen can infect rice florets at flowering stage where it destroys the ovary and leaves the style, stigma and anther buried intact in the spore mass. The individual grains are transformed into galls, which at first are covered by a silvery-white membrane that ruptures exposing yellow-orange chlamydospores subsequently turning green, olive-green, and then greenish black at maturity (Figure 1) [5] [10].
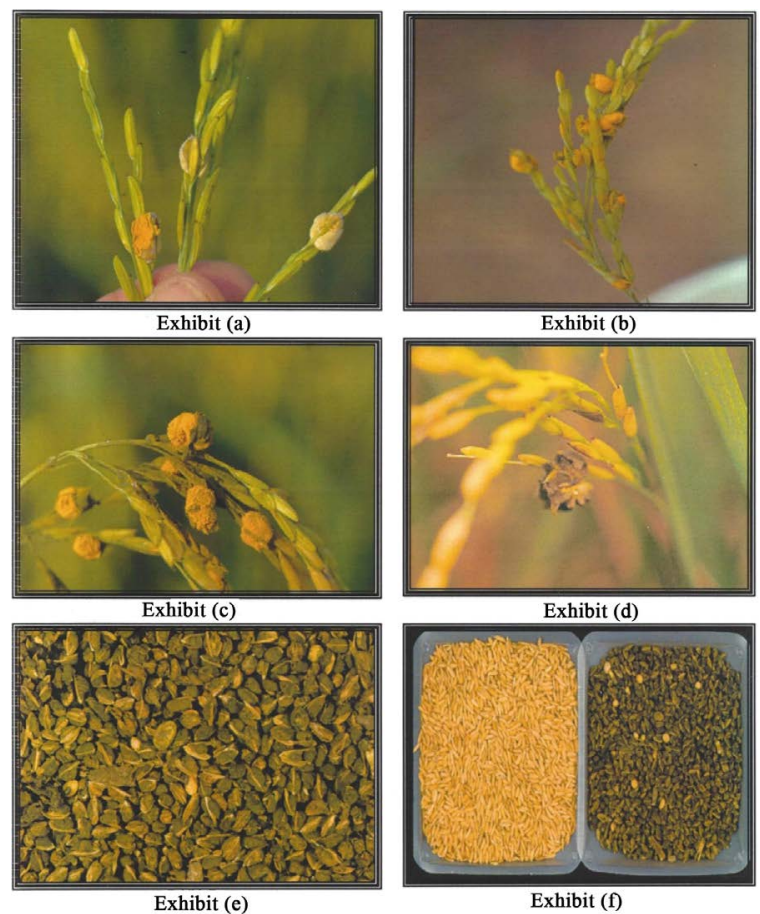

Figure 1. Disease development of rice false smut. (a) Young false smut galls. Notice the creamy or white appearance; (b) Premature false smut galls. Notice the orange color; (c) Mature false smut galls; (d) \& (e) Eventually they become greenish to black and erupt; (f) Left: Healthy rice kernels from the same fields as controls. Right: Massive false smut galls collected from rice plants infected with false smut disease. Notice the contrast between the large, hard, dark false smut galls and the healthy kernels. 
False smut has also been reported to infect the tassels of maize [18] and possibly other cereal crops [19]. False smut disease in rice was first reported in India in 1878 [20] and has occurred sporadically in other rice-growing areas of the world since [14] [21] [22]. It was first reported in US rice-growing areas over a century ago in 1906 [23]. Since the late 1990s and early 2000s, the disease has increased in severity and has been severe in India, China, and the US. This is thought to be due to high susceptibility among the high-yielding rice cultivars that have been introduced and increased applications of nitrogen fertilizer [5] [11] [24] [25].

Reports from China, India, and Japan indicate that false smut galls produce mycotoxins known as ustiloxins [26]-[31]. Ustiloxins A and B are the most common, but the amount and type of toxins produced by false smut galls varies greatly depending on geographical and environmental conditions. Ustiloxins are cyclic peptides (Figure 2), which are toxic to plants and animals by interfering with microtubule function, thereby inhibiting mitosis [22] [26]-[28] [30] [32] [33]. While galls can be removed from rough rice by screening to minimize these problems, this increases the expense of handling and milling of rice having significant numbers of galls and decreases the perceived quality by purchasers. Therefore, false smut disease reduces the economic value of rice both through potential toxicity to people and animals, and reduced value due to discoloration.

In 1998 false smut disease was common in the rice-growing areas of the southern US [22]-[24] [34] [35], when cool temperatures and wet conditions occurred during the maturation stages of the rice crops. This study was undertaken to monitor the safety of the US rice supply by determining if the $U$. virens strain(s) causing false smut disease in rice fields of Arkansas produced ustiloxin toxins at levels sufficient to cause toxicity in plant and animal systems. Given the limited management options for this disease, it is important to understand the potential impact of ustiloxins produced in galls under US conditions.

\section{Materials and Methods}

\subsection{Rice False Smut Galls}

Samples ( $\sim 5 \mathrm{~kg}$ ) of rice false smut galls (RFSGs) were collected by hand in 1998 from heavily-infected mature rice plants in Arkansas fields using 1 gallon sealable plastic bags. In Arkansas, false smut disease was severe, especially in the northeastern part of the state where abnormally high rainfall occurred in late July during the reproductive stages of rice. RFSG samples were collected again in 1999 from Arkansas, although the disease pressure was lower than the previous year. The summer of 1999 was not favorable for false smut development. These samples were transferred to a screen-bottomed tray, and allowed to airdry in a ventilated hood for 3 to 4 days. Dried, cleaned, greenish to black mature RFSBs were combined, mixed well, put in a clean, autoclaved 20 $\mathrm{kg}$ white cloth bag and wrapped with another autoclaved bag to prevent spills and dampness during storage. The samples were stored at $-80^{\circ} \mathrm{C}$ until used for chemical and biological studies.

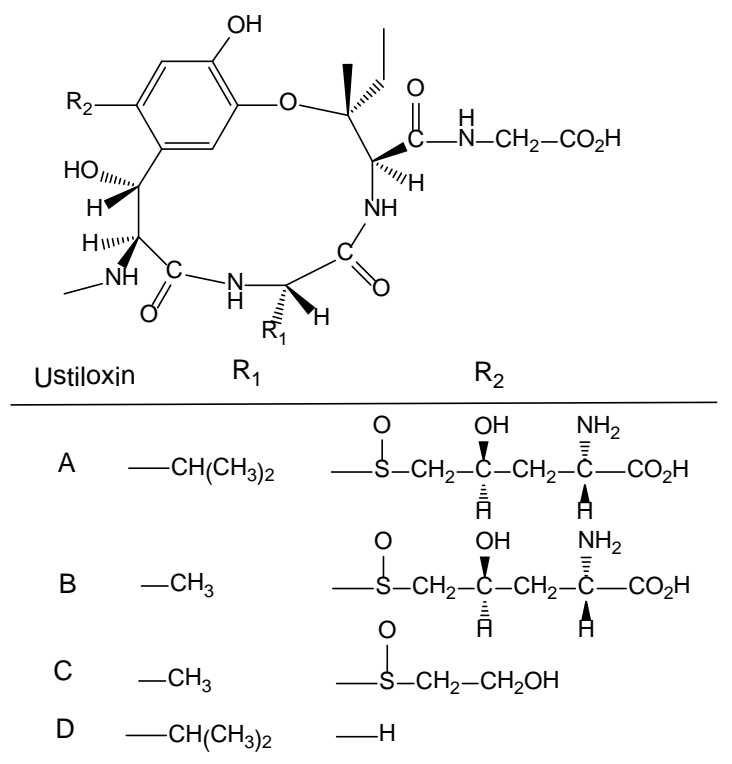

Figure 2. The chemical structures of the ustiloxins. 


\subsection{Preparation of Crude and Cell-Free Extracts of Rice False Smut Galls}

RFSGs (500 g) were thawed at room temperature, soaked in $5 \mathrm{~L}$ autoclaved distilled water for at least $2 \mathrm{hr}$ before extraction. The soaked RFSBs were homogenized in a blender and filtered through three layers of cheese cloth. Half of the filtered extract was stored frozen at $-80^{\circ} \mathrm{C}$ for backup and chemical analysis use, and the remaining half was filtered through $0.45 \mu \mathrm{m}$ membrane filters (Nalgene disposable filter ware, Nalgene Company, Rochester, NY), freeze-dried, and the residue stored at $-20^{\circ} \mathrm{C}$ as RFSG cell-free extract (RFSGCFE). For bioassays, RFSGCFE was reconstituted to $500 \mathrm{mg} / \mathrm{ml}$ concentrations in aqueous sterile stock solutions.

\subsection{Fractionation of Rice False Smut Gall Crude Extract}

RFSGCFE was subjected to the exact same fractionation procedure at half scale as was used previously by Koiso et al. [26] to purify ustiloxins from false smut galls caused by $U$. virens infection of rice panicles in Japan. Briefly, reconstituted RFSGCFE was fractionated by applying RFSGCFE dissolved in water to a $\mathrm{C}_{18}$ reversed phase column, washing with water, eluting with $20 \%$ aqueous methanol and evaporating to dryness in a rotary evaporator. Koiso et al. [26] reported that the $20 \%$ aqueous methanol-eluted fraction contained a mixture of ustiloxins A, B, C, D and E. This fraction, called rice false smut gall ustiloxin fraction (RFSGUF), was used for toxicity testing, and for ustiloxin analysis by TLC methods using ninhydrin spray reagent for detection as described by Koiso et al. [26] [27].

\subsection{Phytotoxicity Assays}

The phytotoxicity of RFSGCFE and RFSGUF was evaluated in a small aquatic plant, duckweed (Lemnapausicostata Helgelm. 6746), and in the normal host plant, rice (Oryza sativa).

\subsubsection{Duckweed Phytotoxicity Assays}

Three plants of duckweed with 3 fronds each were used determine the phytotoxicity of RFSGUF and RFSGCFE according to the method of Tanaka et al. [35] with some modification. Briefly, three duckweed plants bearing 3 fronds each were transferred from a production tank with sterilized forceps to each well of a sterile 24-well tissue culture plate with low evaporation lid containing test media with or without RFSGUF or RFSGCFE. RFSGUF and RFSGCFE were reconstituted in duckweed growth medium and tested for phytotoxicity in four replicate wells containing $1.5 \mathrm{ml}$ solutions. RFSGCFE was tested at $0,625,1250,2500,5000$, and 10,000 $\mu \mathrm{g} / \mathrm{ml}$ and RFSGUF was tested at $0,1,2,4,9,19,38,75,150,300$, and $600 \mu \mathrm{g} / \mathrm{ml}$. Duckweed assay cultures were incubated in a growth chamber at $25^{\circ} \mathrm{C}$ under continuous light for $96 \mathrm{hr}$. Duckweed plantlets were observed for signs of phytotoxicity after 24, 48, 72, and $96 \mathrm{hr}$. The percent of growth reduction was determined based on counting the number of fronds per plantlet (Figure 3).

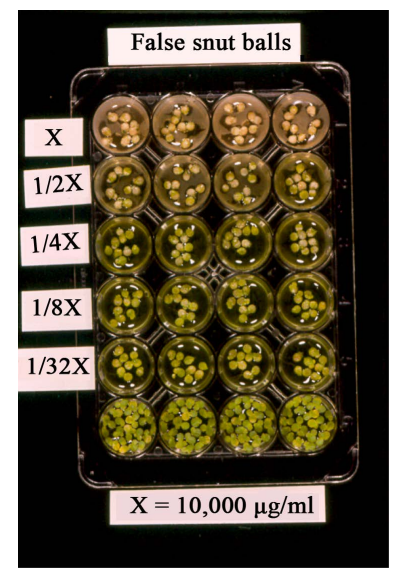

Figure 3. Duckweed plant bioassays. Control healthy duckweed plants cultured in growth media containing no rice false smut gall cell free extracts (RFSBCFE) are present in the unlabeled bottom row of wells; they are compared to unhealthy duckweed plants treated with RFSBCFE at the indicated dilutions in the upper rows of wells. Notice the growth reduction and necrotic and dead frond tissue in the treated wells in comparison to the control fronds. Also the phytotoxic effects were increased with increase in the concentration. 


\subsubsection{Rice Cultivar Germination Bioassays}

About $200 \mathrm{~g}$ of seeds of 13 rice cultivars were measured and 50 healthy seeds with no visual physical damage were selected (Table 1 and Table 2) for this assay. Each set of seeds was soaked in reconstituted RFSGCFE solution at 1000 and $10,000 \mu \mathrm{g} / \mathrm{ml}$ for $2 \mathrm{hr}$. Soaked seeds were placed on sterile moist blue germination papers previously soaked in RFSGCFE solution, which was placed in Petri dishes (15 cm diam.) using sterilized forceps.

Table 1. Phytotoxicity of rice false smut gallcell free extract (RFSGCFE) at $1000 \mu \mathrm{g} / \mathrm{ml}$ on seed germination of rice cultivars after 14 days.

\begin{tabular}{cccc}
\hline Rice cultivars & Seed germination (\%) & Root length reduction (\%) & Shoot length reduction (\%) \\
Bengal & $98 \pm 3$ & $0 \pm 0$ & $0 \pm 0$ \\
Cypress & $92 \pm 0$ & $26 \pm 2.0$ & $10 \pm 2.6$ \\
$9,201,179$ & $90 \pm 3$ & $15 \pm 1.5$ & $12 \pm 1.6$ \\
Kaybonnet & $100 \pm 0$ & $0 \pm 0$ & $7 \pm 1.0$ \\
$9,021,176$ & $90 \pm 3$ & $3 \pm 1.8$ & $8 \pm 1.7$ \\
Katy & $96 \pm 0$ & $0 \pm 0$ & $2 \pm 0.1$ \\
Lemont & $98 \pm 3$ & $0 \pm 0$ & $0 \pm 0$ \\
$9,401,188$ & $96 \pm 0$ & $0 \pm 0$ & $10 \pm 1.1$ \\
Laffite & $90 \pm 9$ & $27 \pm 0.9$ & $53 \pm 0.9$ \\
Jefferson & $88 \pm 0$ & $27 \pm 0.9$ & $0 \pm 0$ \\
Dixie & $94 \pm 3$ & $0 \pm 0$ & $0 \pm 0$ \\
LGRU & $82 \pm 8$ & $14 \pm 1.9$ & $9 \pm 0.7$ \\
AB 647 & $72 \pm 0$ & $0 \pm 0$ & 0.9 \\
\hline
\end{tabular}

Percent seed germination, reduction of root and shoot lengths are relative to controls not treated with rice false smut gall cell free extract at 1000 $\mu \mathrm{g} / \mathrm{ml}$. Data are presented as mean of the germinated seeds out of 50 original \pm standard error. Reduction of root and shoot length data are for rice plants that germinated.

Table 2. Phytotoxicity of rice false smut gall cell free extract (RFSGCFE) at 10,000 $\mu \mathrm{g} / \mathrm{ml}$ on seed germination of rice cultivars after 14 days.

\begin{tabular}{cccc}
\hline Rice cultivars & Seed germination (\%) & Root length reduction (\%) & Shoot length reduction (\%) \\
\hline Bengal & $88 \pm 6$ & $65 \pm 0.4$ & $0 \pm 0$ \\
Cypress & $80 \pm 11$ & $83 \pm 0.4$ & $39 \pm 1.4$ \\
$9,201,179$ & $90 \pm 3$ & $83 \pm 0.3$ & $50 \pm 1.0$ \\
Kaybonnet & $92 \pm 0$ & $89 \pm 0.1$ & $67 \pm 1.0$ \\
$9,021,176$ & $88 \pm 0$ & $79 \pm 0.4$ & $40 \pm 1.1$ \\
Katy & $88 \pm 6$ & $77 \pm 0.5$ & $25 \pm 0.9$ \\
Lemont & $92 \pm 0$ & $88 \pm 0.2$ & $64 \pm 0.8$ \\
$9,401,188$ & $90 \pm 3$ & $56 \pm 0.3$ & $46 \pm 0.7$ \\
Laffite & $88 \pm 11$ & $78 \pm 0.5$ & $22 \pm 1.1$ \\
Jefferson & $90 \pm 3$ & $82 \pm 0.2$ & $33 \pm 1.0$ \\
Dixie & $100 \pm 0$ & $92 \pm 0.3$ & $53 \pm 0.9$ \\
LGRU & $66 \pm 14$ & $86 \pm 0.8$ & $51 \pm 0.8$ \\
AB 647 & $74 \pm 3$ & $88 \pm 0.7$ & $46 \pm 1.2$ \\
\hline
\end{tabular}

Percent seed germination, reduction of root and shoot lengths are relative to controls not treated with rice false smut gall cell free extract at 10,000 $\mu \mathrm{g} / \mathrm{ml}$. Data are presented as mean of germinated seeds out of 50 original \pm standard error. Reduction of root and shoot length data are for rice plants that germinated. 
All Petri dishes were incubated at $32^{\circ} \mathrm{C} \pm 2{ }^{\circ} \mathrm{C}$ growth chamber at $60 \%$ humidity for 14 days. During the first three days each plate was covered with foil to create dark conditions to enhance germination. On the fourth day, foils were removed and the plates were incubated an additional ten days under $60 \%$ humidity with an alternating $12 \mathrm{hr}$ dark and light cycle. RFSGCFE solution was added to each plate at the appropriate concentration as needed to keep the plate from drying. Effects of RFSGCFE on seed germination, root reduction (cm), shoot inhibition (cm) and any symptoms were assessed visually every day. Data on germination percentage, root and shoot length in cm were recorded at end of the experiment and compared to respective controls of each cultivar. The control plates received only sterile distilled water throughout the length of the experiment.

\subsection{Mice Feeding Test of Rice False Smut Galls}

A preliminary study was conducted to determine if mice will eat RFSGs. Mouse diet and 10 mice were purchased from a pet store in Peoria, IL.RFSGs were added to mouse diet at $0 \%, 10 \%, 25 \%$, and $50 \%(\mathrm{wt} / \mathrm{wt}$ ) and the mixture ground together to 20 mesh size particles in a coffee grinder. Two mice were used for each RFSG: diet ratio. Mice were weighed in the beginning and after 5 days feeding the mixtures. The mixed diet was also weighed at the beginning and end of the test and any symptoms and mortality were recorded. The mice refused to eat mixed diets at $25 \%$ and $50 \%$ RFSBs. However, no significant (Student's $t$-test) changes were seen between the mice fed $0 \%$ or $10 \%$ RFSGs in diet with respect to weight gain, food consumption or mouse behavior. Therefore, the RFSG larger scale feeding study was designed and conducted using only $10 \%$ RFSBs in diet with 5 mice for each treatment and a control group fed only ground mouse chow. Weight gain, food consumption and visual signs or symptoms of mouse behavior were recorded after feeding ad libitum for 14 days [36].

\subsection{Cytotoxicity Assays}

The cytotoxicity of RFSGCFE and RFSGUF was evaluated in four mammalian cell line assays as described previously [36]-[38]. Briefly, the following mammalian cell lines were used: H4TG6-thioguanine-resistant minimal deviation rat hepatoma cell line with some differentiated liver properties purchased from American Type Culture Collection (Manassas, VA, USA); MDCKMadin Darby canine kidney epithelial cells with some differrentiated kidney properties purchased from American Type Culture Collection (Manassas, VA, USA); NIH3T3 Swiss mouse fibroblasts obtained from S. Aaronson, National Cancer Institute, Bethesda, MD, USA; and KA3ITKirsten murine sarcoma virus transformed 3T3 Swiss mouse fibroblasts obtained from R. Pollack, Columbia University, New York, NY.RFSGCFE and RFSGUF were tested at various concentrations: 0, 4, 8, 16, 32, 62.5, 125 , 250, 500, and $1000 \mu \mathrm{g} / \mathrm{ml}$. Also included as positive controls were miscellaneous mycotoxins prepared in this laboratory and some macrocyclic trichothecenes (see Table 5). Macrocyclic trichothecenes were tested at a lower range of concentrations: $0,1,2,4,8,16,32,62.5,125,250,500,1000 \mathrm{ng} / \mathrm{ml}$, to compare the toxicity of RFSB materials and known standard toxins. Macrocyclic trichothecenes were purchased from Sigma Chemical Co., (St. Louis, MO), except trichoverin A and trichoverin B which were gifts of Dr. Bruce Jarvis, University of Maryland, College Park, MD. Each cell line was cultured in 96-well trays at $10^{4}$ cells/well in triplicate in $0.2 \mathrm{ml}$ of $5 \%$ (vol/vol) calf serum (Hy Clone Laboratories, Logan, UT, USA) in Du1becco's modified Eagle's medium containing a dilution of each toxin. The cultures were incubated under normal culture conditions until wells with no toxin to become confluent. The cells were fixed with $10 \%$ formalin in saline and stained with $0.05 \%(\mathrm{w} / \mathrm{v})$ crystal violet in $20 \%(\mathrm{v} / \mathrm{v})$ aqueous methanol. Cell number was estimated by counting at least 250 cells in 5 microscope fields in 3 wells. Thus, the criteria for viability were attachment and proliferation. The concentration causing half-maximal inhibition of cell proliferation $\left(\mathrm{IC}_{50}\right)$ was estimated graphically by interpolation using straight lines fitted by the least squares method to plots of cell number versus log concentration.

\section{Results}

RFSGCFE caused dramatic phytotoxic effects in the duckweed plant bioassay at $600 \mu \mathrm{g} / \mathrm{ml}$ and higher. Phytotoxic symptoms included close to $100 \%$ growth reduction in duckweed fronds, necrotic lesions, light brownish color fronds and mortality (Figure 3).

RFSGCFE was subjected to the same fractionation procedure used previously by Koiso et al. [26] in the purification of ustiloxins from false smut galls caused by $U$. virens infecting rice in Japan. Analysis of RFSGCFE and RFSGUF by thin layer chromatography with detection by ninhydrin spray reagent as described by Koiso et 
al. [26] showed no positive reaction when the TLC plates treated with ninhydrin reagent, which would have detected the free amino groups in ustiloxins, if they were present. RFSGUF showed phytotoxic effects in the duckweed plant bioassay at $19 \mu \mathrm{g} / \mathrm{ml}$ (Table 3). The phytotoxic effects increased with increasing concentrations of RFSGUF (Table 3).

RFSGCFE and RFSGUF were also examined for phytotoxic effects on the host plant, rice, by measuring effects on the seeds of 13 cultivars, specifically effects on seed germination, root reduction, and shoot inhibition. RFSGCFE caused phytotoxic effects on various rice cultivars at both 1000 and 10,000 $\mu \mathrm{g} / \mathrm{ml}$ (Table 1 and Table 2, and Figure 4). The phytotoxic effects were greater on rice cultivars that were treated at $10,000 \mu \mathrm{g} / \mathrm{ml}$ of

Table 3. Phytotoxicity of rice false smut gall ustiloxin fraction (RFSGUF) on duckweed (Lemnapausicostata) plantlets in axenic culture.

\begin{tabular}{|c|c|c|c|}
\hline \multirow{2}{*}{ Ustiloxin fractionconcentration $(\mu \mathrm{g} / \mathrm{mL})$} & \multicolumn{3}{|c|}{ Phytotoxicityeffects after $96 \mathrm{hr}^{\mathrm{a}}$} \\
\hline & Symptoms ${ }^{c}$ & Growth increase $^{\mathrm{d}}$ & Growth inhibition (\%) \\
\hline Controls $^{\mathrm{b}}$ & 0 & $19.8 \pm 2.6$ & 0 \\
\hline 1 & 0 & $20.5 \pm 0.7$ & 0 \\
\hline 2 & 0 & $20.0 \pm 2.8$ & 0 \\
\hline 4 & 0 & $20.0 \pm 4.2$ & 0 \\
\hline 9 & 50 & $21.5 \pm 0.7$ & 0 \\
\hline 19 & 75 & $9.0 \pm 1.4$ & 53.8 \\
\hline 38 & 100 & $4.0 \pm 1.4$ & 79.8 \\
\hline 75 & 100 & $3.0 \pm 0.0$ & 84.8 \\
\hline 150 & 100 & $5.0 \pm 0.0$ & 74.7 \\
\hline 300 & 100 & $4.0 \pm 0.0$ & 79.8 \\
\hline 600 & 100 & $3.0 \pm 0.0$ & 84.8 \\
\hline
\end{tabular}

${ }^{\mathrm{a}}$ Data are presented as a mean of four replicates \pm standard error; ${ }^{\mathrm{b}}$ Controls were duckweed plantletfronds which received only duckweed growth media in axenic culture; 'Symptoms: the phytotoxic damage rating scale assigned values of $0 \%$ for healthy growth, $25 \%$ for necrotic tissue with light brownish color around edges of the fronds, $50 \%$ for necrotic tissue with light brownish color covering a half of the fronds, $75 \%$ for necrotic tissue with light brownish color covering almost two thirds of the fronds, and $100 \%$ for necrotic tissue with light brownish color covering the fronds completely, which results in $100 \%$ plant mortality; ${ }^{\mathrm{d}}$ Growth increase was calculated based on the number of the fronds.

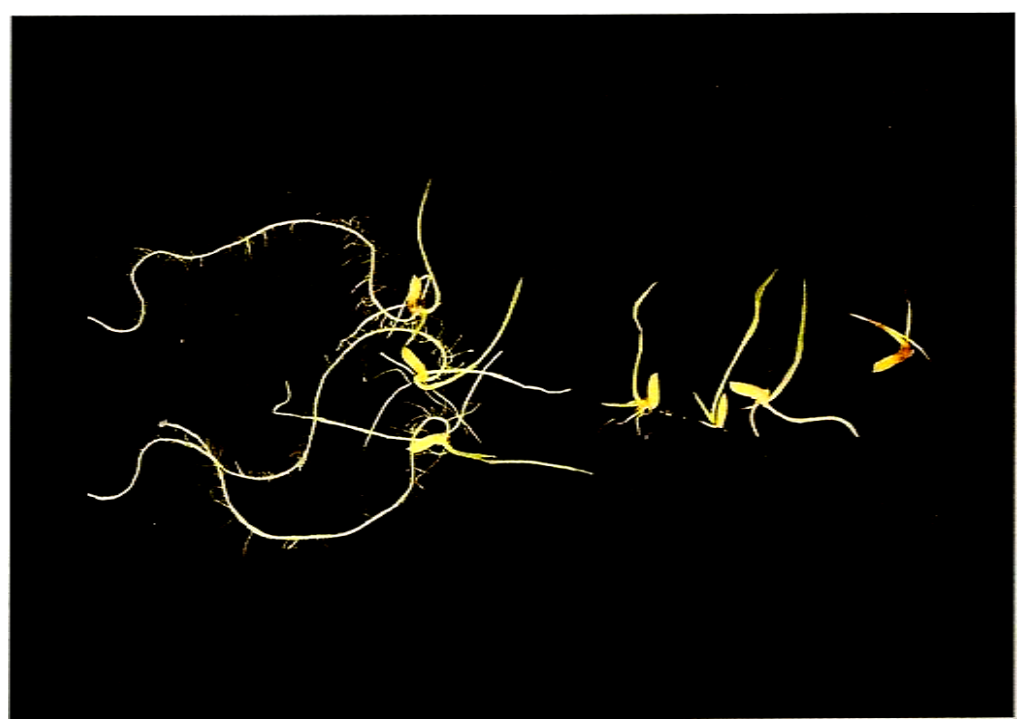

Figure 4. Rice germination bioassay. Three healthy control "Dixie" rice seedlings, which were treated with autoclaved distilled water in a column on the left, are compared to four unhealthy seedlings on the right, which were treated with the rice false smut gall cell free extracts (RFSBCFE) at $10,000 \mu \mathrm{g} / \mathrm{ml}$. 
RFSGCFE. Four rice cultivars (Bengal, Katy, 9401188, and Dixie) showed near complete resistance to RFSGCFE at $1000 \mu \mathrm{g} / \mathrm{ml}$. With the same four rice cultivars at 10,000 $\mu \mathrm{g} / \mathrm{ml}$ RFSGCFE, they were not resistant except the Bengal cultivar preserved shoot length under those conditions (Table 2).

Mammalian toxicity of rice false smut galls and their extracts were examined in vivo and in vitro. Mice exhibited marked feed refusal activity for blends of ground rice false smut galls and mouse chow at $25 \%$ and $50 \%$ (wt/wt) rice false smut galls. However, there was no detectable feed refusal activity for a blend of $10 \%$ (wt/wt) rice false smut galls in mouse chow. No significant difference (Student's $t$-test) was observed in weight gain, food consumption and visual signs or symptoms of mouse behavior in a feeding trial comparing consumption of $10 \%$ (wt/wt) rice false smut galls in mouse chow with pure mouse chow during feeding ad libitum for 14 days (Table 4) [36].

RFSGCFE and RFSGUF were also examined for cytotoxicity in four mammalian cell lines in comparison with a series of other known mycotoxins, including macrocyclic trichothecenes (Table 5). RFSGCFE exhibited no detectable cytotoxicity at $200 \mu \mathrm{g} / \mathrm{ml}$ (i.e., the $\mathrm{IC}_{50}$ is $>200 \mu \mathrm{g} / \mathrm{ml}$ ). RFSGUF exhibited modest cytotoxicity, with $\mathrm{IC}_{50}$ values in the range from 10 to $100 \mu \mathrm{g} / \mathrm{ml}$ with the four cell lines tested (Table 5). This level of cytotoxicity was much lower than that of the other mycotoxins included in the study as positive controls.

Attempts to isolate the fungus that causes the false smut galls on rice using conditions that allow facile isolation of major plant fungal pathogens were unsuccessful. However the homogenate of false smut galls sprayed on rice under control conditions in greenhouse and in the field induced the disease (Abbas et al., unpublished data).

\section{Discussion}

The results of this study indicate that false smut galls of rice in the southern USA contain only trace levels of phytotoxic and cytotoxic activity caused by unidentified agent(s). Thus, $U$. virens infecting rice in southern USA is profoundly different from the Asian rice-infecting $U$. virens, which has been reported to produce galls with

Table 4. Effect of rice false smut galls on mice fed a $10 \%$ mixture of smut galls and mice chow*

\begin{tabular}{cccccc}
\hline Treatment & No. of mice & $\begin{array}{c}\text { Avg. initial body wt. } \\
(\mathrm{g})\end{array}$ & $\begin{array}{c}\text { Avg. final body } \\
\text { wt. (g) }\end{array}$ & $\begin{array}{c}\text { Total avg. food } \\
\text { consumed (g) }\end{array}$ & $\begin{array}{c}\text { Symptoms of } \\
\text { toxicity }\end{array}$ \\
\hline Control (mouse chow) & 5 & $27.8 \pm 1.7$ & $31.6 \pm 1.2$ & $68.0 \pm 3.6$ & None \\
$10 \%$ False smut ball in diet & 5 & $27.2 \pm 2.9$ & $31.0 \pm 2.3$ & $67.8 \pm 1.3$ & None \\
\hline
\end{tabular}

${ }^{*}$ The control and treatment groups of mice were fed for 14 days. Data are presented as the average of five replicates \pm SEM. None $=$ no detectable toxic effect or death. There was no significant difference in final body weights or food consumed at 14 days (Student's $t$-test).

Table 5. Cytotoxicity of false smut cell free extract and the ustiloxin fraction.

\begin{tabular}{|c|c|c|c|c|}
\hline \multirow{2}{*}{ Preparation } & \multicolumn{4}{|c|}{ Concentration causing half maximal inhibition of cell proliferation ( $\left.\mathrm{IC}_{50}, \mathrm{ng} / \mathrm{ml}\right)$} \\
\hline & NIH3T3 & KA31T & H4TG & MDCK \\
\hline False Smut Cell Free Extract (RFSGCFE) & $>200,000$ & NT & $>200,000$ & $>200,000$ \\
\hline Ustiloxin fraction (RFSGCFE) & $50,000 \pm 3500$ & $10,000 \pm 900$ & $100,000 \pm 4800$ & $50,000 \pm 3900$ \\
\hline Wortmannin & $15,000 \pm 2200$ & $10,000 \pm 3600$ & $20,000 \pm 3700$ & $20,000 \pm 4200$ \\
\hline Atranone B & $7000 \pm 800$ & $3500 \pm 50$ & $7500 \pm 2800$ & $5000 \pm 0.0$ \\
\hline Trichoverin A & $>1000$ & $150 \pm 3.4$ & $200 \pm 10.2$ & $500 \pm 13.4$ \\
\hline Trichoverin B & $>1000$ & $100 \pm 3.3$ & $200 \pm 9.3$ & $400 \pm 11.2$ \\
\hline Roridin E & $3.5 \pm 0.04$ & $1.5 \pm 0.8$ & $4 \pm 0.03$ & $3.5 \pm 1.1$ \\
\hline Roridin $\mathrm{H}$ & $10 \pm 0.09$ & $3.5 \pm 0.06$ & $4 \pm 0.04$ & $5 \pm 0.6$ \\
\hline Verucarin A & $1.5 \pm 0.01$ & $0.5 \pm 0.0$ & $1.5 \pm 0.03$ & $1 \pm 0.42$ \\
\hline Verucarin J & $3.5 \pm 0.15$ & $1.5 \pm 0.01$ & $2 \pm 0.03$ & $2 \pm 0.06$ \\
\hline Epi-isororidin E & $20 \pm 4.2$ & $5 \pm 0.42$ & $20 \pm 3.3$ & $15 \pm 1.06$ \\
\hline
\end{tabular}

Results are the average of three replicates \pm standard error. NT $=$ Not tested. 
abundant ustiloxins [26] [27]. The results of this study do not distinguish between the following three possible identities for the agent(s) that cause the trace levels of phytotoxicity and cytotoxicity observed in false smut galls of rice in southern USA: 1) the phytotoxicity and cytotoxicity is caused by traces of ustiloxins at levels below detection by ninhydrin spray reagents and thin layer chromatography; 2) the phytotoxicity and cytotoxicity is caused by a different known or novel mycotoxin produced by $U$. virens; or 3) the phytotoxicity and cytotoxicity is caused by a different known or novel mycotoxin produced by a different species of fungus involved in a secondary infection of rice false smut galls of the southern USA. Takahashi et al. [30] reported that false smut galls vary greatly in their production of ustiloxins ranging from none to large amounts of toxins. The results reported here indicate that false smut galls appear to affect the appearance but not the food safety of rice in the United States. Preliminary results suggest that spores are removed by the shelling and milling process (Abbas et al., unpublished data).

Rice has been reported to be more resistant to mycotoxins than other major crops such as corn and wheat for two reasons [39] [40]. First, its kernels develop and mature in a tightly closed protective husk and the kernels are separated in the head so that infection cannot easily spread from kernel to kernel. Second, rice crops are mostly produced in areas where they are grown in a rainy season, but harvested in the dry season and thus storage conditions are more nearly ideal for keeping fungi from germinating and causing post-harvest disease. In contrast, corn and wheat are grown in temperate regions where rain and moisture occur throughout the year [40].

\section{Conclusion}

$U$. virens isolates, which caused false smut disease in rice in southern USA, differed from Asian isolates in that they did not produce detectable ustiloxins and caused no detectable toxicity in mouse feeding studies, although there was detectable phytotoxicity in vitro. Thus, false smut in southern United States affects the appearance, but not the food safety of rice grown there.

\section{Acknowledgements}

The author thanks Bobbie J. Johnson, Kathryn Marchesini, and Adrea Robinson USDA-ARS, Stoneville, MS, for their valuable technical assistance. We thank Mr. Ron Vesonder for conducting the mouse feeding study.

\section{Disclaimer}

Trade names are used in this publication solely for the purpose of providing specific information. Mention of a trade name, propriety product, or specific equipment does not constitute a guarantee or warranty by the USDAARS and does not imply approval of the named product to exclusion of other similar products.

\section{References}

[1] International Rice Research Institute (2014) Rice Production Course: Importance of Rice. www.knowledgebank.irri.org/ericeproduction/Importance_of_Rice.htm

[2] Yunich, R. (2011) Rice Industry Adds \$34 Billion to Nation’s Economy. USA Rice Federation, 1-4. www.usarice.com

[3] Lee, F.N. and Gunnell, P.S. (1992) False Smut. In: Webster, P.K. and Gunnell, P.S., Eds., Compendium of Rice Diseases, American Phytopathological Society Press, St. Paul, 28.

[4] Kou, Y. and Wang, S. (2012) Toward an Understanding of the Molecular Basis of Quantitative Disease Resistance in Rice. Journal of Biotechnology, 159, 283-290.

[5] Sanghera, G.S., Ahanger, M.A., Kashyap, S.C., Bhat, Z.A., Rather, A.G. and Parray, G.A. (2012) False Smut of Rice (Ustilaginoidea virens) under Temperate Agro-Climatic Conditions of Kashmir, India. Elixir Bio Technology, 49, 9827-9831.

[6] White, J.F., Sullivan, R., Moy, M., Patel, R. and Duncan, R. (2000) An Overview of Problems in the Classification of Plant-Parasitic Clavicipitaceae. Studies in Mycology, 45, 95-105.

[7] Ashizawa, T., Takahashi, M., Moriwaki, J. and Hirayae, K. (2011) A Refined Inoculation Method to Evaluate False Smut Resistance in Rice. Journal of General Plant Pathology, 77, 10-16. http://dx.doi.org/10.1007/s10327-010-0279-5

[8] Ashizawa, T., Takahashi, M., Arai, M. and Arie, T. (2012) Rice False Smut Pathogen, Ustilaginoideavirens, Invades through Small Gap at the Apex of a Rice Spikelet before Heading. Journal of General Plant Pathology, 78, 255-259. http://dx.doi.org/10.1007/s10327-012-0389-3 
[9] Ladhalaskshmi, D., Laha, G.S., Singh, R., Karthikeyan, A., Mangrauthia, S.K., Sundaram, R.M., Thukkaiyannan, P. and Viraktamath, B.C. (2012) Isolation and Characterization of Ustilaginoideavirens and Survey of False Smut Disease of Rice in India. Phytoparasitica, 40, 171-176. http://dx.doi.org/10.1007/s12600-011-0214-0

[10] Hu, M., Luo, L., Wang, S., Liu, Y. and Li, J. (2013) Infection Processes of Ustilaginoideavirens during Artificial Inoculation of Rice Panicles. European Journal of Plant Pathology, 139, 67-77. http://dx.doi.org/10.1007/s10658-013-0364-7

[11] Fan, J., Guo, Y., Huang, F., Li, Y., Liu, F., Li, L., Xu, Y.J., Zhao, J.Q., Xiong, H., Yu, J.J. and Wang, W. (2014) Epiphytic Colonization of Ustilaginoidea virens on Biotic and Abiotic Surfaces Implies the Widespread Presence of Primary Inoculums for Rice False Smut Disease. Plant Pathology, 63, 937-945.

[12] Guo, X., Li, Y., Fan, J., Li, L., Huang, F. and Wang, W. (2012) Progress in the Study of False Smut Disease in Rice. Journal of Agricultural Science and Technology, 2, 1211-1217.

[13] Fu, R., Ding, L., Zhu, J., Li, P. and Zheng, A. (2012) Morphological Structure of Propagules and Electrophoretic Karotype Analysis of False Smut Villosiclava virens in Rice. Journal of Microbiology, 50, 263-269. http://dx.doi.org/10.1007/s12275-012-1456-3

[14] Biswas, M.C. (2001) False Smut Disease of Rice: A Review. Environment and Ecology, 19, 67-83.

[15] Takahashi, Y. (1896) On Ustilago virens Cooke and a New Species of Tilletia Parasitic on Rice Plant. Shokubutsugaku Zasshi, 10, 16-20. http://dx.doi.org/10.15281/jplantres1887.10.109_16

[16] Hashioka, Y. (1971) Rice Disease in the World, VIII. Diseases Due to Hypocreals, Ascomycetes (Fungal Diseases, No. 5). Riso, 20, 235-258.

[17] Tanaka, E., Ashizawa, T., Sonoda, R. and Tanaka, C. (2008) Villosiclava virens gen. nov., comb. nov. Teleomorph of Ustilaginoidea virens, the Causal Agent of Rice False Smut. Mycotaxon, 106, 491-501.

[18] Abbas, H.K., Sciumbato, G.L. and Keeling, B. (2002) First Report of False Smut of Corn (Zea mays) in the Mississippi Delta. Plant Disease, 86, 1179. http://dx.doi.org/10.1094/PDIS.2002.86.10.1179B

[19] Pataky, J.K. (1999) False Smut. In: White, D.G., Ed., Compendium of Corn Diseases, 3rd Edition, American Phytopathological Society Press, St. Paul, 35.

[20] Cooke, M.C. (1878) Some Extra-European Fungi. Grevillea, 7, 13-15.

[21] Zhou, Y.L., Pan, Y.J., Xie, X.W., Zhu, L.H., Wang, S. and Li, Z.K. (2008) Genetic Diversity of Rice False Smut Fungus Ustilaginoidea virens and Its Pronounced Differentiation of Populations in North China. Journal of Phytopathology, 156, 559-564. http://dx.doi.org/10.1111/j.1439-0434.2008.01387.x

[22] Li, W.L., Li, L.Y., Feng, A.Q., Zhu, X.Y. and Li, J.X. (2013) Rice False Smut Fungus, Ustilaginoidea virens, Inhibits Pollen Germination and Degrades the Integuments of Rice Ovule. American Journal of Plant Sciences, 4, $2295-2304$. http://dx.doi.org/10.4236/ajps.2013.412284

[23] Orton, W.A. (1906) Plant Diseases of 1906. Year Book US Department of Agriculture, US Government Printing Office, Washington DC, 499-508.

[24] Ahonsi, M.O., Adeoti, A.A., Erinle, I.D., Alegbejo, T.A., Singh, B.N. and Sy, A.A. (2000) Effect of Variety and Sowing Date on False Smut Incidence in Upland Rice in Edo State, Nigeria. International Rice Research Notes, 25, 14.

[25] Wang, D.W., Wang, S. and Fu, J.F. (2004) Research Advances on False Smut of Rice. Liaoning Agricultural Sciences, 1, 21-24.

[26] Koiso, Y., Li, Y., Iwasaki, S., Hanaoka, K., Kobayash, T., Sonoda, R., Fujita, Y., Yabgashi, H. and Sato, Z. (1994) Ustiloxins, Antimitotic Cyclic Peptides from False Smut Balls on Rice Panicles Caused by Ustilaginoidea virens. Journal of Antibiotics, 47, 765-773. http://dx.doi.org/10.7164/antibiotics.47.765

[27] Koiso, Y., Natori, M., Iwasaki, S., Sato, S., Sonoda, R., Fujita, R., Yaegashi, H. and Sato, Z. (1992) Ustiloxin: A Phytotoxin and a Mycotoxin from False Smut Balls on Rice Panicles. Tetrahedron Letters, 33, 4157-4160. http://dx.doi.org/10.1016/S0040-4039(00)74677-6

[28] Shan, T.J., Sun, W.B., Liu, H., Gao, S., Lu, S.Q., Wang, M.G., Sun, W.X., Chen, Z.Y., Wang, S. and Zhou, L.G. (2012) Determination and Analysis of Ustiloxins A and B by LC-ESI-MS and HPLC in False Smut Balls of Rice. International Journal of Molecular Sciences, 13, 11275-11287. http://dx.doi.org/10.3390/ijms130911275

[29] Shan, T.J., Sun, W.B., Wang, X.H., Fu, X.X., Sun, W.X. and Zhou, L.G. (2013) Purification of Ustiloxins A and B from Rice False Smut Balls by Macroporous Resins. Molecules, 18, 8181-8199. http://dx.doi.org/10.3390/molecules18078181

[30] Takahashi, M., Ashizawa, T., Yamanaka, N., Arai, M. and Takahashi, Y. (2012) Pathogenic Isolates of Ustilaginoidea virens Differ Greatly in Their Production of Ustiloxin A in Rice False Smut Balls. Japanese Journal of Phytopathology, 78, 305-308. http://dx.doi.org/10.3186/jjphytopath.78.305

[31] Nakamura, K., Izumiyama, N., Ohtsubo, K., Koiso, Y., Iwasaki, S., Sonoda, R., Fujitia, Y., Yaegashi, H. and Sato, K. 
(1992) Lupinosis in Mice Caused by Ustiloxin and a Crude Extract of Fungal Culture of Ustilaginoidea virens (in Japanese with English Summary). Proceedings of the Japanese Association of Mycotoxicology, 35, 41-43.

[32] Li, Y., Koiso, Y., Kobayashi, H., Hashimoto, Y. and Iwasaki, S. (1995) Ustiloxins, New Antimitotic Cyclic Peptides: Interaction with Porcine Brain Tubulin. Biochemical Pharmacology, 49, 1367-1372. http://dx.doi.org/10.1016/0006-2952(95)00072-8

[33] Abbas, H.K., Cartwright, C.D., Sciumbato, G.L., Keeling, B., Vesonder, R.F. and Shier, W.T. (2000) Mycotoxins in False Smut Balls From Rice. Phytopathology, 90, S1.

[34] Rush, M.C., Shahjahan, A.K.M., Groth, D.E. and Jones, J.P. (2000) Outbreak of False Smut of Rice in Louisiana. Plant Disease, 84, 100. http://dx.doi.org/10.1094/PDIS.2000.84.1.100D

[35] Tanaka, T., Abbas, H.K. and Duke, S.O. (1993) Structure-Dependent Phytotoxicity of Fumonisins and Related Compounds in a Duckweed Bioassay. Phytochemistry, 33, 779-785. http://dx.doi.org/10.1016/0031-9422(93)85274-U

[36] Abbas, H.K., Mirocha, C.J. and Shier, W.T. (1984) Mycotoxins Produced from Fungi Isolated from Foodstuffs and Soil: Comparison of Toxicity in Fibroblasts and Rat Feeding Test. Applied and Environmental Microbiology, 48, 654-661.

[37] Abbas, H.K., Shier, W.T. and Mirocha, C.J. (1984) Sensitivity of Cultured Human and Mouse Fibroblasts to Trichothecenes. , 67, 607-610.

[38] Abbas, H.K., Yoshizawa, T. and Shier, W.T. (2013) Cytotoxicity and Phytotoxicity of Trichothecene Mycotoxins Produced by Fusarium spp. Toxicon, 74, 68-75. http://dx.doi.org/10.1016/j.toxicon.2013.07.026

[39] Abbas, H.K. and Shier, W.T. (2009) Chapter 3. Mycotoxin Contamination of Agricultural Products in the Southern United States and Approaches to Reducing It from Pre-Harvest to Final Food Products. In: Appell, M., Kendra, D. and Trucksess, M.W., Eds., Mycotoxin Prevention and Control in Agriculture. American Chemical Society Symposium Series 1031, Oxford University Press, Oxford, 37-58.

[40] Abbas, H.K., Cartwright, R.D., Windham, G.L., Xie, W., Shier, W.T. and Mirocha, C.J. (2000) The Presence of Mycotoxins and Fungi in Rice and Corn in the Southern United States. Bulletin of the Institute for Comprehensive Agricultural Sciences Kinki University, 8, 23-28. 
Scientific Research Publishing (SCIRP) is one of the largest Open Access journal publishers. It is currently publishing more than 200 open access, online, peer-reviewed journals covering a wide range of academic disciplines. SCIRP serves the worldwide academic communities and contributes to the progress and application of science with its publication.

Other selected journals from SCIRP are listed as below. Submit your manuscript to us via either submit@scirp.org or Online Submission Portal.
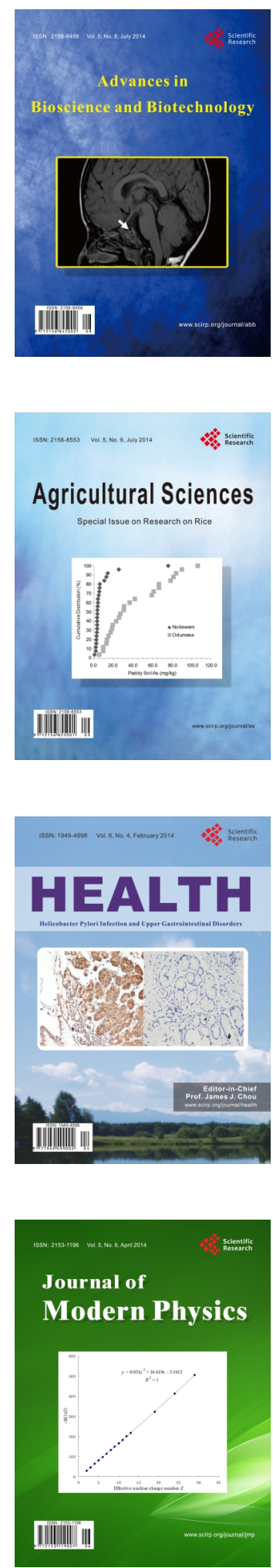
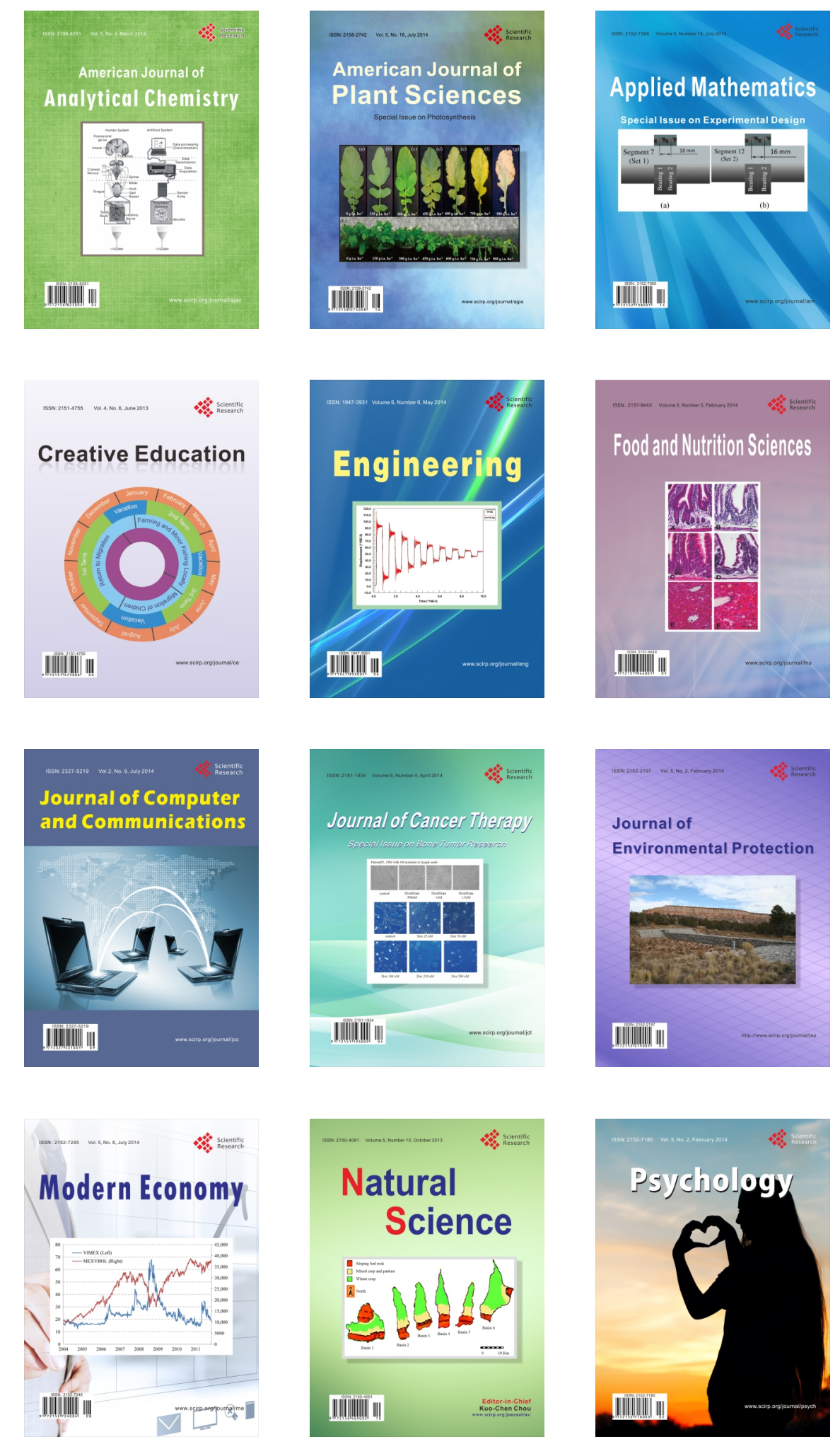